\title{
Synthesis: stratigraphy and age control for IODP Sites U1394, U1395, and U1396 offshore Montserrat in the Lesser Antilles ${ }^{1}$
}

\author{
M.F. Coussens, ${ }^{2}$ D. Wall-Palmer, ${ }^{3}$ P.J. Talling, ${ }^{3}$ S.F.L. Watt, ${ }^{4}$ S.J. Hatter, ${ }^{2}$ M. Cassidy, ${ }^{5}$ M. Clare, ${ }^{2}$ \\ M. Jutzeler, ${ }^{3}$ R. Hatfield, ${ }^{3}$ M. McCanta, ${ }^{3}$ K.S. Kataoka, ${ }^{3}$ D. Endo, ${ }^{3}$ M.R. Palmer, ${ }^{3}$ A. Stinton, ${ }^{3}$ \\ A. Fujinawa, ${ }^{3}$ G. Boudon, ${ }^{3}$ A. Le Friant, ${ }^{3}$ O. Ishizuka, ${ }^{3}$ T. Gernon, ${ }^{2}$ T. Adachi, ${ }^{3}$ M. Aljahdali, ${ }^{3}$ \\ C. Breitkreuz, ${ }^{3}$ A. J. Frass, ${ }^{3}$ M.J. Hornbach, ${ }^{3}$ E. Lebas, ${ }^{6}$ S. Lafuerza, ${ }^{3}$ F. Maeno, ${ }^{3}$ M. Manga, ${ }^{3}$ \\ M. Martinez-Colon, ${ }^{3}$ J. McManus, ${ }^{3}$ S. Morgan, ${ }^{3}$ T. Saito, ${ }^{3}$ A. Slagle, ${ }^{3}$ K.S.V. Subramanyam, ${ }^{3}$ \\ Y. Tamura, ${ }^{3}$ J. Trofimovs, ${ }^{7}$ B. Villemant, ${ }^{3}$ F. Wang, ${ }^{3}$ and the Expedition 340 scientists $^{3}$
}

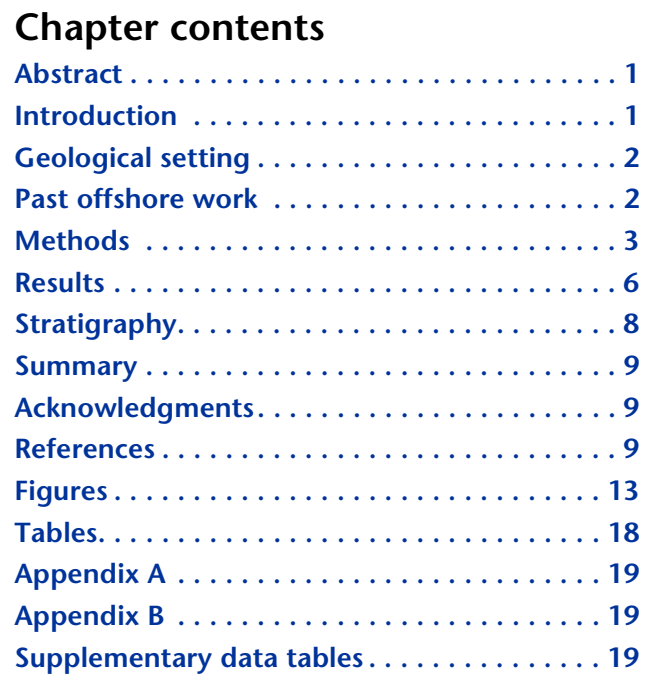

${ }^{1}$ Coussens, M.F., Wall-Palmer, D., Talling, P.J., Watt, S.F.L, Hatter, S.J., Cassidy, M., Clare, M., Jutzeler, M., Hatfield, R., McCanta, M., Kataoka, K.S., Endo, D., Palmer, M.R., Stinton, A., Fujinawa, A., Boudon, G., Le Friant, A., Ishizuka, O., Gernon, T., Adachi, T., Aljahdali, M., Breitkreuz, C., Frass, A.J., Hornbach, M.J., Lebas, E., Lafuerza, S., Maeno, F., Manga, M., Martinez-Colon, M., McManus, J., Morgan, S., Saito, T., Slagle, A., Subramanyam, K.S.V., Tamura, Y., Trofimovs, J., Villemant, B., Wang, F., and the Expedition 340 Scientists, 2015. Synthesis: stratigraphy and age control for IODP Sites U1394, U1395, and U1396 offshore Montserrat in the Lesser Antilles. In Le Friant, A., Ishizuka, O., Stroncik, N.A., and the Expedition 340 Scientists, Proc. IODP, 340: Tokyo (Integrated Ocean Drilling Program Management International, Inc.). doi:10.2204/iodp.proc.340.204.2016 ${ }^{2}$ School of Ocean and Earth Science, University of Southampton, Southampton SO14 3ZH, United Kingdom. Correspondence author: mfc1e12@soton.ac.uk

${ }^{3}$ See Expedition 340 Scientists' addresses.

${ }^{4}$ School of Geography, Earth and Environmental Sciences, University of Birmingham, Birmingham B15 2TT, United Kingdom.

${ }^{5}$ Institute of Geosciences, Johannes Gutenberg, University Mainz, 55128 Mainz, Germany.

${ }^{6}$ Institut de Physique du Globe de Paris, CNRS UMR 7154, 75238 Paris Cedex 05, France.

${ }^{7}$ Queensland University of Technology, GPO Box 2434,

Brisbane QLD 4001, Australia.

\section{Abstract}

This data report focuses on Holes U1394B, U1395B, and U1396C located offshore Montserrat. These holes were drilled during Integrated Ocean Drilling Program Expedition 340 and contain deposits associated with the growth and decay of the volcanic island of Montserrat. Hole U1394B dates to $\sim 353 \mathrm{ka}$ and is composed of 17 bioclastic turbidites, 24 mixed turbidites, 55 volcaniclastic turbidites, and 32 tephra fall layers within a background stratigraphy of hemipelagic marine mud. Hole U1395B dates to older than 1 Ma and contains 18 bioclastic turbidites, 27 mixed turbidites, 43 volcaniclastic turbidites, and 52 tephra fall layers. The uppermost $7 \mathrm{~m}$ of Hole U1396C covers $\sim 1$ My of stratigraphy and contains 1 bioclastic turbidite, 1 mixed turbidite, 9 volcaniclastic turbidites, and 13 tephra fall layers. Tephra fall and some volcaniclastic deposits are associated with episodes of island building, whereas bioclastic turbidites, mixed turbidites, and some volcaniclastic turbidites are associated with large landslide events from Montserrat.

\section{Introduction}

It is important to understand the significant hazards posed by volcanic islands such as Montserrat, which include various types of volcanic eruption and flank collapses that can trigger tsunamis. The best record of these past events may be found offshore in marine sequences because most of the eruption or landslide material ends up offshore (Le Friant et al., 2010). Terrestrial outcrops are particularly hard to interpret because of erosion or burial of deposits. Marine sediments are also more easily dated as a result of intervening layers of hemipelagic mud (Trofimovs et al., 2012). Integrated Ocean Drilling Program (IODP) Expedition 340 in 2012 provided some of the few long cores from offshore oceanic volcanic islands (>1 Ma) and the first that penetrated through major submarine landslide deposits (Le Friant et al., 2012, 2015). During the Expedition a total of nine sites were drilled offshore Montserrat, Martinique, and Dominica in the Lesser Antilles (Expedition 340 Scientists, 2012) (Fig. F1). 
Montserrat is an outstanding natural laboratory for understanding the growth and decay of a volcanic island. It comprises four volcanic centers: the Soufrière Hills, South Soufrière Hills, Centre Hills, and Silver Hills centers. The Soufrière Hills volcano has erupted episodically since 1995, with the last major eruption in 2010. These subaerial eruptions have been studied in unusual detail (Wadge et al., 2014; Druitt and Kokelaar, 2002). The offshore record has also been studied in unprecedented detail. Previous offshore work includes arguably the most complete set of shallow ( $<10$ meters below seafloor; mbsf) sediment cores available for a volcanic island (Trofimovs et al., 2006, 2008, 2010, 2013; Le Friant et al., 2008; Cassidy et al., 2013, 2014a, 2014b), the first repeat bathymetric surveys of offshore pyroclastic flow deposits emplaced during recent eruptions (Le Friant et al., 2004, 2009, 2010; Trofimovs et al., 2006, 2008), and detailed 2-D and 3-D seismic reflection surveys (Deplus et al., 2001; Lebas et al., 2011; Watt et al., 2012a, 2012b; Crutchley et al., 2013; Karstens et al., 2013; Le Friant et al., 2004, 2015). In particular, this previous work identified a series of large (1-20 $\left.\mathrm{km}^{3}\right)$ offshore landslide deposits with much larger volumes than any of the 1995-recent eruptions. These landslides are termed Deposit 1 to Deposit 8 (Deplus et al., 2001; Le Friant et al., 2004; Lebas et al., 2011; Watt et al., 2012a, 2012b).

IODP Expedition 340 provides important information on the growth and decay of volcanic islands in the Lesser Antilles. Three sites (U1394, U1395, and U1396) were successfully drilled offshore Montserrat; a fourth site (U1393) recovered little material and is not included here. Site U1394 is located $\sim 10 \mathrm{~km}$ southeast of Montserrat, Site U1395 is located 25 $\mathrm{km}$ southeast of Montserrat, and Site U1396 is located $\sim 35 \mathrm{~km}$ southwest of Montserrat (Fig. F1). Sites U1394 and U1395 are situated in the BoullianteMontserrat Graben, which is a major route for turbidites originating from southeast of Montserrat. Site U1396 is located on a topographic high to capture a record of fallout from eruptions that sent material southwest of the island. Identifying and dating the deposits will enable a better understanding of how volcanic island arcs evolve on long timescales $(>1$ My). Results are summarized as two oversized-format figures shown in "Appendix A" and "Appendix B." Here we outline the methods used to obtain these figures and the key results that they show.

\section{Geological setting}

Montserrat is situated in the Lesser Antilles Island arc formed from the westward subduction of the North American plate beneath the Caribbean plate (Pindell and Barrett, 1990). The Lesser Antilles arc is bifurcated from Dominica toward the north, resulting in a volcanically extinct easterly arc and a volcanically active western arc. Activity is thought to have migrated to the more westerly arc during the mid-Miocene as the consequence of changing subduction dynamics (Bouysse and Westercamp, 1990).

There are four volcanic centers on the island of Montserrat. For the past $290 \mathrm{ky}$, eruptive activity has focused at Soufrière Hills, with a brief interlude of activity at South Soufrière Hills at 120-150 ka (Harford et al., 2002). Activity at Centre Hills has been dated between 950 and $550 \mathrm{ka}$ and at Silver Hills between 2600 and $1200 \mathrm{ka}$ (Harford et al., 2002). Volcanic activity has been characterized by dome eruptions, landslides, and small vulcanian style eruptions based on observations of recent eruptions and studies on subaerial deposits (Kokelaar, 2002; Smith et al., 2007; Roobol and Smith, 1998).

An eruption of the Soufrière Hills volcano started in 1995 , causing evacuation of much of the island, including the capital city of Plymouth. At the time of writing (2015), the southern part of the island is still within an exclusion zone. The last major eruption was in February 2010. This eruption sequence comprised multiple phases of dome building and dome collapse episodes that generated pyroclastic flows. In June 2003, the largest globally documented volcanic dome collapse in historical times occurred, $210 \times 10^{6}$ $\mathrm{m}^{3}$ of material (Trofimovs et al., 2006, 2008).

\section{Past offshore work}

Offshore seismic surveys have identified more than seven debris avalanche deposits with volumes varying between 0.3 and $20 \mathrm{~km}^{3}$ (Deplus et al., 2001; Lebas et al., 2011; Watt et al., 2012a, 2012b; Crutchley et al., 2013; Karstens et al., 2013; Boudon et al., 2007) (Fig. F1). The most recent large landslide occurred at 12-14 ka. Efforts at Site U1393 were unsuccessful to sample Deposit $1\left(1.8 \mathrm{~km}^{3}\right)$, which was emplaced toward the southeast of the island. A smaller landslide (Deposit 5; $0.3 \mathrm{~km}^{3}$ ) originated from the shelf edge southwest of the island at a similar or slightly later time (Cassidy et al., 2012, 2013; WallPalmer et al., 2014). A much larger landslide (Deposit 2; $20 \mathrm{~km}^{3}$ ) occurred at $\sim 130 \mathrm{ka}$ and overlies an even larger landslide, Deposit 8 , as shown in seismic data sets (Lebas et al., 2011; Watt et al., 2012a, 2012b; Le Friant et al., 2015). Both Deposits 2 and 8 contain areas of well-bedded reflectors, as well as large blocks (Watt et al., 2012a, 2012b). It appears that emplacement of material from the volcano onto the surrounding seafloor resulted in even more wide- 
spread failure of seafloor sediment (Watt et al., 2012a, 2012b; Le Friant et al., 2015).

A comprehensive set of $>70$ shallow (up to $6 \mathrm{~m}$ long) vibrocores and gravity cores has been collected from around the island (Fig. F1). These cores have been used to correlate and date a series of turbidites that were emplaced in the last $130 \mathrm{ky}$ (Trofimovs et al., 2006, 2008, 2010, 2012, 2013; Cassidy et al., 2013, 2014a, 2014b) (Figs. F1, F2). An unusually large number of accelerator mass spectrometry (AMS) radiocarbon dates have precisely constrained the ages of events in the last 40 ky (Fig. F2). These events include an erosive stack of turbidites at 11.5-14 ka that may be linked to emplacement of Deposit 1 . Two smaller volume turbidites were emplaced at 2 and 6 ka, probably linked to later failures of English's Crater (Boudon et al., 2007; Trofimovs et al., 2013) (Fig. F2). An oxygen isotope stratigraphy from these vibrocores helps establish the ages of older events, including basaltic-rich turbidites at $110 \mathrm{ka}$. A detailed analysis of the CAR-MON2 core collected southwest of Montserrat provides information on events during the last 250 ky (Le Friant et al., 2008). Cassidy et al. $(2013,2014 a, 2014 b)$ provide information on landslide and turbidite events during the last $110 \mathrm{ky}$ on the southeast side of the island. More recently, WallPalmer et al. (2014) discuss events recorded at Site U1396 during the last 250 ky. In general, this extensive set of shallower cores is very useful for understanding the stratigraphy and age of layers in the upper parts of the IODP sites described here.

\section{Methods}

\section{Core sites}

Sites U1394, U1395, and U1396 were drilled during March 2012. Site U1394 is located $\sim 10 \mathrm{~km}$ southwest of Montserrat, and Site U1395 is located $\sim 25 \mathrm{~km}$ southwest of Montserrat. Sites U1394 and U1395 are located within the Boulliant-Montserrat Graben, which funnels turbidites originating from southeast of Montserrat. Two holes were drilled at each of Sites U1394 and U1395. Hole U1394A recovered $24.17 \mathrm{~m}$ of core with $\sim 41 \%$ disturbed core, and Hole U1394B recovered $137.42 \mathrm{~m}$ of core with an estimated core disturbance of $\sim 29 \%$. Hole U1394A had poor core recovery below $35 \mathrm{~m}$ because of the rotary drilling technique used below this depth. Hole U1394B has a gap between 15 and 60 mbsf because of the rotary drilling technique; a subsequent change to advanced piston coring produced much better core recovery. Hole U1395A recovered $124.29 \mathrm{~m}$ of core with 7\%$13 \%$ estimated core disturbance, and Hole U1395B recovered $127.52 \mathrm{~m}$ of core with $12 \%-16 \%$ core disturbance.
Site U1396 is located $\sim 35 \mathrm{~km}$ southeast of Montserrat on a topographic high. Three holes were drilled at Site U1396. Hole U1396A recovered $140.51 \mathrm{~m}$ of core with $<1 \%$ estimated core disturbance, and Hole U1396C recovered $145.92 \mathrm{~m}$ of core with 3\% estimated core disturbance. The interval between 5 and 15 mbsf was deformed in Hole U1396A during drilling; therefore, a short $(10 \mathrm{~m})$ third hole (U1396B) was drilled to recover this $5-15 \mathrm{~m}$ interval. Holes U1394B, U1395B, and U1396C were the most complete; thus, initial work has primarily been conducted on these holes.

\section{Core logging}

Initial core logging was done during Expedition 340 on the $\mathrm{R} / \mathrm{V}$ JOIDES Resolution, including detailed graphical logs (at a scale of $1-10 \mathrm{~cm}$ ) and analysis of grain compositions. This ship-based work is captured on the visual core descriptions (VCDs) (see "Core descriptions"). Further core logging of key core sections was completed at the IODP Gulf Coast Repository (GCR) in College Station, Texas (USA), after the expedition, together with more analyses of grain composition ("Appendix A").

\section{Identification of coring artifacts-especially sand sucked in during piston coring}

It is important to distinguish in situ deposits from the artifacts of coring. This issue is analyzed in more detail by Jutzeler et al. (2014). In particular, advanced piston coring can suck in layers of massive sand, which could be mistaken for turbidites. Jutzeler et al. (2014) outline a method for identifying which sand layers are an artifact of piston core suckin. For instance, these sand layers tend to terminate at the bottom of the individual sections of IODP piston core. Sand layers that may have been sucked in are shown by shaded boxes on the logs in "Appendix A" and "Appendix B."

\section{Core sampling}

Cores were stored at the GCR. Samples were taken from hemipelagic mud for oxygen isotope analysis and also from every event deposit to determine type and emplacement mechanism of each event found within the cores. Sample volumes varied between $>1$ and $10 \mathrm{~cm}^{3}$ depending on abundance and thickness of the unit; care was taken to avoid disturbed sections of the core. Sample processing and analysis was conducted at the National Oceanography Centre, Southampton (NOCS, United Kingdom), and Plymouth University (United Kingdom). All samples were dried in a cool oven at $40^{\circ} \mathrm{C}$ for $24 \mathrm{~h}$ prior to removal of fines by wet sieving over a $63 \mu \mathrm{m}$ sieve. Both fine 
and coarse fractions were collected and dried in a cool oven for $24 \mathrm{~h}$. Some sample for grain-size analysis was kept aside and not sieved.

\section{Grain sizes}

Grain size distributions were used to distinguish between submarine turbidity current and fallout deposits, as outlined below. Laser diffraction was used to measure grain size distributions using a Malvern (Mastersizer 2000) particle size analyzer. This instrument has a range of $0.2-2000 \mu \mathrm{m}$. A volume of 25 $\mathrm{mL}$ of reverse osmosis water with $0.05 \%$ sodium hexametaphosphate dispersant was added to $1 \mathrm{~cm}^{3}$ of unsieved sample and left overnight on a shaking table. Samples were analyzed three times using the Mastersizer, and accuracy was monitored using standard size particles (32 and $125 \mu \mathrm{m}$ ).

\section{Componentry-composition of layers}

The composition of layers provides key information on their origin ("Appendix B"). Initial component analyses were completed on the vessel during Expedition 340, dividing grains into one of seven classifications:

1. Vesicular pumice,

2. Scoria clasts,

3. Nonvesiculated lava clasts,

4. Vesiculated lava clasts,

5. Volcaniclastic clasts,

6. Sedimentary clasts including bioclasts, or

7. Other clasts (e.g., hydrothermal clasts).

Using smear slides, abundance estimates were made using an area chart. Data are shown in "Appendix A."

More detailed componentry analysis was conducted at NOCS using $>63 \mu \mathrm{m}$ material from all volcanicrich units and some bioclastic-rich units from Holes U1394B, U1395B, U1396A, and U1396C. For each sample, at least 300 grains were point-counted using a field counting method, where all grains within the microscope field of view are counted. Grains were divided into one of six classifications:

1. Vesicular pumice clasts,

2. Nonvesicular lava,

3. Altered lithic clasts,

4. Crystal and glass fragments,

5. Mafic scoria clasts, or

6. Bioclasts.

This follows the classification of Le Friant et al. (2008) and Cassidy et al. (2014b). Data are shown in "Appendix A" and Table 204_STO3.CSV.

\section{Classification of deposit types in cores}

Five main types of deposit are defined: hemipelagic mud, bioclastic turbidites, mixed turbidites, volcaniclastic turbidites, and tephra fall layers.

Hemipelagic mud is easily identifiable, as it has relatively high mud content with a brown-yellow color and interspersed foraminifers. However, in some cases hemipelagic mud can be difficult to distinguish from a bioclast-rich turbidite, as both may comprise muddy sand rich in bioclasts. This situation occurs when the hemipelagic mud has a higher sand content, perhaps due to contamination by material winnowed by ocean currents.

It can be problematic to distinguish turbidity current deposits (turbidites) from tephra fall layers. We refer the reader to Cassidy et al. (2014b) for a fuller discussion of how to distinguish fallout deposits from turbidites. Here we define the deposit types according to the following consistent criteria:

- Bioclastic turbidites: $>70 \%$ bioclasts.

- Mixed turbidites: 30\%-70\% bioclasts.

- Volcaniclastic turbidites: $<30 \%$ bioclasts and a Folk and Ward (1957) sorting coefficient $>0.5$ (phi).

- Tephra fall: $<30 \%$ bioclasts, Folk and Ward (1957) sorting coefficient $<0.5$ (phi), and $<20 \mathrm{~cm}$ thick.

\section{$\mathrm{Pb}$ isotopes}

Montserrat is situated in an active island arc. Guadeloupe is a volcanic island nearby both Montserrat and the IODP sites; therefore, visible tephra layers from Guadeloupe are likely to feature within the IODP holes. Using lead isotopes, deposits from Montserrat and Guadeloupe can be distinguished, as volcanic rocks from Guadeloupe are relatively enriched in radiogenic lead (Cassidy et al., 2012).

Tephra from Hole U1396C was analyzed for lead isotopes. For each sample, $200 \mathrm{mg}$ of pumice or scoria clasts was picked out and leached in $4 \mathrm{~mL}$ of $6 \mathrm{M}$ $\mathrm{HCl}$ at $140^{\circ} \mathrm{C}$ for $1-2 \mathrm{~h}$ in sealed Teflon vials. Samples were then left on a hot plate at $130^{\circ} \mathrm{C}$ for $24 \mathrm{~h}$ to dissolve in $\mathrm{HF}-\mathrm{HNO}_{3}$. Samples were left to dry, and then a further $0.5 \mathrm{~mL}$ of concentrated HCL and 0.5 $\mathrm{mL}$ of concentrated $\mathrm{HNO}_{3}$ were added, evaporating until dry between each addition. To the remaining residue, $1.5 \mathrm{~mL}$ of $\mathrm{HBr}$ was added and heated for $1 \mathrm{~h}$. A supernatant for column chemistry was then produced by centrifuging samples for $5 \mathrm{~min}$. Isolation of $\mathrm{Pb}$ from the matrix was achieved using AG1-X8 200400 mesh anion exchange resin. Blanks contained $<50 \mathrm{pg}$ of $\mathrm{Pb}$, and the $\mathrm{Pb}$ standard NBS 981 was used. Isotope analyses were conducted on a VG Sector 54 thermal ionization mass spectrometer and multiple 
collector inductively coupled plasma mass-spectrometer (MC-ICP-MS) (Neptune and GV Iso Probe) at NOCS. The double-spike method was used to correct instrumental bias (Ishizuka et al., 2003). Sample preparation and analyses methods follow those of Cassidy et al. (2012).

\section{Dating}

\section{Oxygen and carbon isotope stratigraphies}

The global oxygen isotope curve of seawater fluctuates through time from higher to lower values (Lisiecki and Raymo, 2005). The global oxygen isotope curve is divided into dated marine isotope stages (MIS) representing periods of either higher or lower isotopic values of the global ocean. Marine isotope stages can be identified at Sites U1394, U1395, and U1396 by comparing their respective oxygen isotope records with the global record. Holes U1394B, U1395B, and U1396C were most complete; thus, oxygen isotope stratigraphy was conducted primarily on these holes. However, the upper part of Hole U1394A was more complete than Hole U1394B; thus, the upper $6 \mathrm{~m}$ of Hole U1394A was sampled. Oxygen and carbon isotope analyses were carried out for deposits comprising the upper $\sim 250 \mathrm{ky}$ period of each site, corresponding to the upper $6 \mathrm{~m}$ of Hole U1394A and 92-166 $\mathrm{m}$ of Hole U1394B, the upper $44 \mathrm{~m}$ of Hole U1395B, and the upper $7 \mathrm{~m}$ of Hole U1396C. For isotope analyses, hemipelagic intervals were sampled every $7 \mathrm{~cm}$ for Holes U1394A, U1394B, and U1395B. For Hole U1396C, hemipelagic intervals were sampled every $5 \mathrm{~cm}$. Oxygen isotope stratigraphy was used in combination with biostratigraphy and AMS dating to improve identification of marine isotope stages and sedimentary hiatuses at these sites.

Samples were analyzed at Plymouth University. Twenty Globigerinoides ruber specimens between 250 and $355 \mu \mathrm{m}$ in size were picked from each hemipelagic sample and reacted with $100 \%$ phosphoric acid at $90^{\circ} \mathrm{C}$ for $2 \mathrm{~h}$. The resulting $\mathrm{CO}_{2}$ was analyzed using an Isoprime Instruments continuous flow mass spectrometer with a Gilson multiflow carbonate autosampler. Oxygen and carbon isotope values $\left(\delta^{18} \mathrm{O}\right.$ and $\left.\delta^{13} \mathrm{C}\right)$ are given as per mil (\%o) deviations in the isotope ratios $\left({ }^{18} \mathrm{O} /{ }^{16} \mathrm{O}\right.$ and $\left.{ }^{13} \mathrm{C} /{ }^{12} \mathrm{C}\right)$ calibrated against Vienna Peedee belemnite (VPDB) using internal standards NBS-19, IAEA-CO-8, and IAEA-CO-9. Five NBS-19 standards were also evenly distributed throughout the individual isotope runs to correct for daily drift. The mean standard deviation on replicate analyses was $0.17 \%$ for $\delta^{18} \mathrm{O}$ and $0.19 \%$ for $\delta^{13} \mathrm{C}$.

\section{AMS radiocarbon dating}

Four samples from the upper $4 \mathrm{~m}$ of Hole U1395B (aged < $57 \mathrm{ka}$ ) were AMS dated as part of this study. Site U1395 is located near the drill site of Core JR123-12V, described by Trofimovs et al. (2013) (Figs. F1, F2). AMS samples selected were beneath two of the largest turbidites in the uppermost $4 \mathrm{~m}$ of Hole U1395B (Fig. F2). The upper turbidite is a normally graded bioclastic turbidite $107 \mathrm{~cm}$ thick; the lower turbidite is a normally graded mixed turbidite 116 $\mathrm{cm}$ thick. Two samples were taken beneath each turbidite. For further details see Table T1 and Figure F2.

Approximately 1000 pristine (not reworked) tests of Globigerinoides ruber $>150 \mu \mathrm{m}$ in size were picked ( 17 mg) and sonically cleaned for each sample. Radiocarbon dates were measured at Scottish Universities Environmental Research Council (SUERC) using their in-house protocol (see Trofimovs et al., 2013). The AMS dates for the lower two analyses in Hole U1395B are close to the analytical limit and so are reported as an uncalibrated age of older than $45 \mathrm{ka}$.

\section{Biostratigraphy}

Offshore of Montserrat, planktonic foraminifer datum species do not follow the standard zonation of Wade et al. (2011) during the last $250 \mathrm{ky}$ (WallPalmer et al., 2014) and were not used for stratigraphy. However, the distribution of Globorotalia menardii was used, following the zonation previously published offshore of Montserrat by Le Friant et al. (2008).

Calcareous nannofossils in the $<63 \mu \mathrm{m}$ fraction of hemipelagic samples were analyzed using scanning electron microscopy (SEM). Dry pieces of sediment were adhered to metal stubs using silver paint then sputter-coated with gold. The zonation of Kameo and Bralower (2000) for the Caribbean Sea was used to determine the nannofossil stratigraphy for the three sites.

\section{Paleomagnetism}

Paleomagnetism can be used to date Holes U1394B, U1395B, and U1396C. During the deposition of volcanic and sedimentary rocks, magnetic minerals align to Earth's magnetic field. When the rocks are compacted, the magnetic minerals become fixed, thus preserving the direction of Earth's magnetic field within the rock record. Periodically, Earth's polarity reverses; the ages of these magnetic reversals are well constrained. Pole reversals can be found within Holes U1394B, U1395B, and U1396C by analyzing the natural remnant magnetization (NRM) of the cores. 
Data were collected during Expedition 340 (Hatfield, 2015; also see the "Methods" chapter [Expedition 340 Scientists, 2013]). Archive-half core sections were analyzed every $2.5 \mathrm{~cm}$ before and after alternating field demagnetization in a peak field of $20 \mathrm{mT}$ and an additional step of $10 \mathrm{mT}$, if time and core flow allowed. NRM measurements were also made over a $15 \mathrm{~cm}$ long interval before and after each core section and were used to monitor background magnetic moment and allowed deconvolution of the response of the pickup coils. With no onboard deconvolution, measurements from the top and bottom 10 $\mathrm{cm}$ of each section were omitted from analysis, as these regions are most susceptible to volumetric edge effects associated with instrument response functions. Analyses were conducted using a $2 \mathrm{G}$ Enterprises model 760R superconducting rock magnetometer (SRM) with superconducting quantum interference devices (SQUIDs) and an in-line automated alternating field demagnetizer. Pickup coil response functions for $x-, y$-, and $z$-axes were 6.1, 6.2, and $9.9 \mathrm{~cm}$, respectively. The measured area at each interval is then integrated over $\sim 100 \mathrm{~cm}^{3}$ (Richter et al., 2007). Measurement of an empty tray followed by background drift correction allowed estimation of the ambient noise level at $\sim 2 \times 10^{-6} \mathrm{~A} / \mathrm{m}$. For further details see the "Methods" chapter (Expedition 340 Scientists, 2013). Revised reversal ages from Ogg et al. (2012) were used.

\section{Results}

This section summarizes the stratigraphy, composition, and dating at each of the three sites (shown in "Appendix A" and "Appendix B"). Raw data are included in "Supplementary data tables."

\section{Unit identification}

Tephra fall and some volcaniclastic deposits are associated with episodes of island building, whereas bioclastic turbidites, mixed turbidites, and some volcaniclastic turbidites are associated with collapse events from Montserrat.

Unit types were defined using grain size and componentry criteria, as described previously. Grain size data can be found in Table 204_ST01.CSV, grain size data analyses in Table 204_ST02.CSV, and componentry data can be found in Table 204_STO3.CSV. Hole U1394B includes around 17 bioclastic turbidites, 24 mixed turbidites, 55 volcaniclastic turbidites, and 32 tephra fall layers. Hole U1395B contains 18 bioclastic turbidites, 27 mixed turbidites, 43 volcaniclastic turbidites, and 52 tephra fall layers. The uppermost $7 \mathrm{~m}$ of Hole U1396C contains 1 bio- clastic turbidite, 1 mixed turbidite, 9 volcaniclastic turbidites, and 13 tephra fall layers.

Lead isotopes were used to identify the source of fallout units, although only a few of the fallout layers could be sampled for logistical reasons. Two tephra units in Hole U1396C were found to have a Guadeloupe signature $\left({ }^{208} \mathrm{~Pb} /{ }^{204} \mathrm{~Pb}>38.85 ;{ }^{206} \mathrm{~Pb} /{ }^{204} \mathrm{~Pb}>\right.$ 19.1; Fig. F4; Table T2); thus, most visible tephra units present in Holes U1394B, U1395B, and U1396C are likely to originate from Montserrat.

\section{Dating of units}

We outline the available age control for the three sites in "Appendix A." This age control was obtained using a combination of AMS radiocarbon dating, oxygen isotope stratigraphies, biostratigraphic zones, and paleomagnetic stratigraphies.

\section{AMS radiocarbon dating}

Two AMS radiocarbon dates were obtained from Hole U1395B at 2.3-2.5 mbsf (Table T1; "Appendix $\left.\mathrm{A}^{\prime \prime}\right)$. AMS dates of 10.4 and $12.7 \mathrm{ka}$ assisted correlations to layers dated by Trofimovs et al. (2013) (Fig. F2). Two additional samples located further down Hole U1395B were found to be too old ( $>43.5 \mathrm{ka}$ ) for radiocarbon dating.

\section{Correlation to units dated previously}

Turbidites in the upper 3-5 m of Sites U1394 and U1395 can be correlated to turbidites in adjacent vibrocores, whose ages are well constrained by numerous radiocarbon dates (Trofimovs et al., 2013). These correlations are shown in Figures F2 and F3 and allow turbidites in the upper parts of Holes U1394B and U1395B to be dated more precisely. Below recent turbidites from the 1995 eruption are turbidites at $\sim 2, \sim 3$, and $6 \mathrm{ka}$ (Trofimovs et al., 2013). The $6 \mathrm{ka}$ turbidite is relatively thick at Site U1395 (Fig. F3). The 2 and $6 \mathrm{ka}$ events are thought to originate from collapses of English's Crater on land, whereas the 3 ka turbidite may be the result of a more local carbonate platform failure (Trofimovs et al., 2013). The $6 \mathrm{ka}$ turbidite is underlain by thick bioclastic-rich turbidites that were emplaced at 11.5-14 ka and are most likely associated with landslide Deposit 1 (Fig. F3) (Trofimovs et al., 2013). Radiocarbon dating shows that the 11.5-14 ka turbidity current was particularly erosive. Mafic-rich turbidites dated to $\sim 110 \mathrm{ka}$ by Trofimovs et al. (2013) may also be found at Sites U1394 and U1395 (Fig. F3).

\section{Oxygen isotope stratigraphies}

Oxygen isotope stratigraphies were developed for Sites U1394, U1395, and U1396 ("Appendix A"). 
Raw data are available in Table 204_ST04.CSV. Each site will be described in turn below.

\section{Site U1394}

The oxygen isotope record at Site U1394 is incomplete because of poor core recovery. Hole U1394A is largely incomplete, and Hole U1395B has minimal core recovery between 15 and 60 mbsf. Seismic surveys also identify a chaotic section between 15 and 95 mbsf (M. Vardy, pers. comm., 2015), suggesting the sediments in this 15-95 mbsf interval may not be in situ ("Appendix A").

Site U1394 is located within $8 \mathrm{~km}$ of 18 shallow vibrocores described by Trofimovs et al. (2013) (Fig. F1) as part of an extensive core survey that correlates units across the Boulliant-Montserrat Graben and to the southwest of Montserrat (Trofimovs et al., 2013; Cassidy et al., 2013). Units within the upper $15 \mathrm{~m}$ of stratigraphy from Site U1394 can be correlated with units described by Trofimovs et al., 2013. These include the 2-1.5, 6, 14, 74-59, and 103-99 ka turbidites described by Trofimovs et al. (2013), which can be correlated to units within Hole U1394B (Fig. F3).

Below $15 \mathrm{mbsf}$ it is difficult to identify marine isotope stages in Hole U1394B, as the core is incomplete. The first occurrence of the nannofossil species Emiliania huxleyi $(250 \mathrm{ka})$ is found at Sites U1395 and U1396 near the marine isotope Stage (MIS) 7/8 boundary ("Appendix B"). In Hole U1394B the first occurrence of E. huxleyi is located at $133 \mathrm{mbsf}$, coinciding with an increase in $\delta^{18} \mathrm{O}$ at $\sim 133$ mbsf. Thus, the increase in $\delta^{18} \mathrm{O}$ in Hole U1394B at $\sim 133 \mathrm{mbsf}$ has been correlated with the MIS 7/8 boundary (Fig. F5; "Appendix B").

\section{Site $U 1395$}

Site U1395 is located near the shallow vibrocore JR123-12V described by Trofimovs et al. (2013) (Fig. F1). Units in the upper $15 \mathrm{~m}$ of Site U1395 can be correlated with units in the shallow vibrocores described by Trofimovs et al. (2013) and Cassidy et al. (2013, 2014a). The $2-1.5,6,14,74-59$, and 110-103 ka turbidites from Trofimovs et al. (2013) can be correlated with units in Hole U1395B (Figs. F2, F3).

Some of the units show evidence of erosion (e.g., the 14 ka turbidity current event is suggested to have removed $\sim 30$ ky of underlying hemipelagic material; Cassidy et al., 2013). Despite erosion, the oxygen isotope record from Hole U1395B correlates well to Core JR 123-12-V and to other shallow vibrocores described by Trofimovs et al. (2013) (Figs. F2, F3). The Hole U1395B isotope record also correlates well to the more complete oxygen isotope record of CARMON2 (Fig. F3) and with the standard global oxygen isotope curve (Imbrie et al., 1984; Prell et al., 1986; Martinson et al., 1987).

\section{Site U1396}

Oxygen isotope stratigraphy of Hole U1396C is mostly complete, as there are fewer erosive events. Site U1396 is located near the site of CAR-MON2 (Le Friant et al., 2008), and the oxygen isotopes correlate well (Fig. F3). Only the uppermost unit, where MIS 2 is absent, shows any evidence of significant erosion (Wall-Palmer et al., 2014) (Fig. F5).

Differences between the data presented here and previously published data can be explained by the use of different methodologies. For example, oxygen isotope analysis of CAR-MON2 was carried out on homogenized $<63 \mu \mathrm{m}$ material, which contains both planktonic and benthic organisms, whereas analysis of Hole U1396C was carried out on a single species of planktonic foraminifer.

\section{Biostratigraphy}

The first occurrence datum of the nannofossil species Emiliania huxleyi $(250 \mathrm{ka})$ was identified at all three sites ("Appendix B"), confirming the position of the boundary between MIS 7 and 8. This datum was particularly useful in Hole U1394B, where erosion and poor core recovery between 16 and $60 \mathrm{mbsf}$ made it difficult to identify particular isotope stages. The zonation of G. menardii was also used in confirming the stratigraphy of and the correlations between Holes U1396C, U1395B, and U1394B ("Appendix B"; Table 204_ST04.CSV). Zones U-Z were identified at Sites U1395 and U1394; however, only Zones U-Y were identified at Site U1396 because of erosion close to the surface.

\section{Paleomagnetic stratigraphies}

Shipboard NRM identifies no paleomagnetic reversals in Hole U1394B, suggesting that all of the core material was deposited in the last $781 \mathrm{ky}$. However, it should be noted that some of the material in Hole U1394B comprises landslide Deposit 2, and this material may have originated elsewhere.

Two paleomagnetic reversals occur in Hole U1395B at 781 and $988 \mathrm{ka}$. They are found at depths of 68.571 and 89.08 mbsf, respectively ("Appendix B"). The exact location of the $781 \mathrm{ka}$ reversal is obscured by a thick volcaniclastic turbidite. At the base of Site U1395, declination begins to change, indicating that a $1072 \mathrm{ka}$ reversal may appear at the base of Hole U1395B. For the sake of this study the boundary of the $1072 \mathrm{ka}$ reversal was placed at $115.45 \mathrm{mbsf}$, at the base of a volcaniclastic turbidite. 
A detailed paleomagnetic stratigraphy was obtained for Site U1396 that stretched back to $\sim 4.5 \mathrm{Ma}$ and comprises 16 reversals ("Appendix B").

\section{Stratigraphy}

The following stratigraphy was seen at the three sites, as shown in "Appendix A." Unit thicknesses are available in Table 204_ST05.CSV.

\section{Site U1394}

The upper $\sim 6 \mathrm{~m}$ of both holes comprises stratigraphy seen previously in shallow cores, as described in detail by Trofimovs et al. (2013). This stratigraphy comprises the 1995-recent eruption products at the very top of the core followed by a series of bioclastic and volcaniclastic turbidites. These include 2 and $6 \mathrm{ka}$ turbidites (Trofimovs et al., 2013) and a stack of turbidites previously dated to $11.5-14 \mathrm{ka}$ by Trofimovs et al. (2013) (Figs. F2, F3). A prominent thick pumice-rich turbidite occurs at $\sim 6-14$ mbsf in Hole U1395B, overlain by a distinctive basaltic-rich unit inferred to be a fallout deposit. The basaltic fallout and pumicious turbidite have been the subject of detailed analysis by Cassidy et al. (2015) and are thought to be associated with landslide Deposit 2 at $\sim 130 \mathrm{ka}$.

A series of relatively thick (3-10 m) turbidites occur between 60 and 120 mbsf ( 130 and $200 \mathrm{ka}$ ) in Hole U1394B ("Appendix B"). These sand layers have variable composition with greater or lesser amounts of bioclastic and volcanic material. Some of these thick turbidites may have been sucked in as an artifact of piston coring (see Jutzeler et al., 2014), and such intervals are shown by shaded boxes in "Appendix A." However, a significant number of these thick turbidite sand layers appear to be in situ.

The interval between 120 and 175 mbsf ( 200 and $350 \mathrm{ka}$ ) in Hole U1394B comprises a greater fraction of hemipelagic muds and has thinner turbidite and fallout layers ("Appendix A"). A thick pumice-rich sand interval at 155-163 mbsf may have been flowin during coring. Thinner bedded turbidites and fallout deposits underlie the pumice-rich sand, below which a thick sand layer forms the base of Hole U1394B.

Hole U1394B includes landslide Deposit 2, which is seen as a chaotic sequence on 2-D seismic profiles (Fig. F1) (Watt et al., 2012a, 2012b). Deposit 2 comprises two parts (Deposits 2a and 2b) in seismic data separated by an interval of continuous reflectors that extend $15 \mathrm{~km}$ downslope (Watt et al., 2012a, 2012b). Analysis of the seismic data suggests that Deposit $2 b$ lies between 16 and 60 mbsf in Hole U1394B, whereas Deposit 2a is located between 60 and 95 mbsf (M. Vardy, pers. comm., 2015). Thus, only Deposit $2 \mathrm{a}$ is sampled in Hole U1394B, as there is very little core recovery between 16 and $60 \mathrm{~m}$. Surprisingly, landslide Deposit 2a comprises a sequence of flat-lying turbidites in Hole U1394B with no evidence of deformation, despite appearing as a chaotic unit in seismic surveys.

\section{Site U1395}

This more distal site is located in the BouillanteMontserrat Graben $\sim 25 \mathrm{~km}$ from the island (Fig. F1). Advanced piston coring ensured good recovery in both holes down to $120-125$ mbsf. A change to rotary drilling resulted in much poorer recovery at deeper levels in the holes ("Appendix A").

The upper $11.5 \mathrm{~m}$ of both holes comprises a series of turbidites separated by hemipelagic mud, capped by a turbidite stack from the 1995-recent eruptions on Montserrat. This turbidite stratigraphy can be correlated to Site U1394 and to the shallow cores described by Trofimovs et al. (2013) (Figs. F2, F3).

A prominent thick turbidite sand layer occurs between $\sim 11.5$ and 18 mbsf at this site. This layer has been attributed to the turbidity current created by Deposit 2 emplacement (130 ka). It is most likely equivalent to the thick pumice-rich turbidite that occurs between 6 and 14 mbsf at Site U1394 ("Appen$\left.\operatorname{dix} A^{\prime \prime}\right)$.

Between 18 and $62 \mathrm{~m}$ ( 130 and $700 \mathrm{ka})$, Holes U1395A and U1395B tend to have more hemipelagic mud and thinly bedded turbidites and tephra fallout layers. There are a small number of thicker $(>1 \mathrm{~m})$ turbidites. Some of these thicker turbidites may be related to flow-in during piston coring (Jutzeler et al., 2014), but others appear to be in situ. Shaded

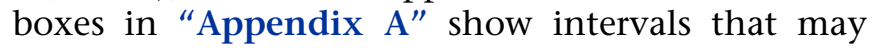
have been sucked in. The lower part of Holes U1395A and U1395B (62-120 mbsf; 700-1000 ka) comprise numerous thin tephra layers $(<10 \mathrm{~cm})$ and thin volcaniclastic turbidites $(<20 \mathrm{~cm})$ with thin intervals $(<50 \mathrm{~cm})$ of hemipelagic mud.

At the base of Hole U1395B ( 1 Ma) lies Deposit 8. This is the largest known debris avalanche deposits from Montserrat, with an estimated volume of 20 $\mathrm{km}^{3}$ (Boudon et al., 2007; Lebas et al., 2011) ("Appendix A," "Appendix B"). Seismic surveys estimate that the top of Deposit 8 lies $\sim 120$ m below the seafloor (M. Vardy, pers. comm., 2015). Below 119 mbsf in Hole U1395B is a coarse, thick (5 m) volcaniclastic turbidite with some evidence of basal flow-in. This unit may be the top of Deposit 8. Unfortunately, a change from advanced piston coring to rotary drilling resulted in poor recovery within Deposit 8 below 120 mbsf. 


\section{Site U1396}

Hole U1396C is generally much finer grained and more thinly bedded than Sites U1394 and U1395. Site U1396 is dominated by tephra fall deposits with additional thin $(<40 \mathrm{~cm})$ turbidites ("Appendix A").

\section{Summary}

The past 1 My of Montserrat's offshore stratigraphy comprises a series of turbidites and tephra fall units that are interleaved with hemipelagic mud. Tephra fall deposits are associated with eruptive activity at Montserrat, although some tephra fall deposits found at Sites U1394, U1395, and U1396 are likely to be from Guadeloupe. Volcaniclastic turbidites may originate from eruptive activity, such as when pyroclastic density currents enter the sea, or alternatively could form from flank collapses at Montserrat. Bioclastic and mixed turbidites are likely to be associated with flank collapse or carbonate shelf collapse events from Montserrat. Holes U1394B, U1395B, and U1396C show that tephra fall and turbidite occurrence is not evenly distributed through time. Within the holes clusters of turbidites and tephra layers are seen. Thicknesses of turbidites also vary through time.

\section{Acknowledgments}

We would like to thank the captain, crew and all staff of the R/V JOIDES Resolution. We would also like to thank all shipboard scientists for their hard work. Radiocarbon dates were funded by the Natural Environment Research Council (NERC) of the United Kingdom under allocation SUERC 1721.0513 at the NERC radiocarbon facility. Thanks to Suzanne MacLachlan at the British Ocean Sediment Core Research Facility (BOSCORF) for providing laboratory space and equipment. We would also like to thank Jan M. Lindsay for her helpful and constructive suggestions during the review process.

\section{References}

Boudon, G., Le Friant, A., Komorowski, J.-C., Deplus, C., and Semet, M.P., 2007. Volcano flank instability in the Lesser Antilles arc: diversity of scale, processes, and temporal recurrence. Journal of Geophysical Research: Solid Earth, 112(B8):B08205. http://dx.doi.org/10.1029/ 2006JB004674

Bouysse, P., and Westercamp, D., 1990. Subduction of Atlantic aseismic ridges and Late Cenozoic evolution of the Lesser Antilles island arc. Tectonophysics, 175(4):349-380. http://dx.doi.org/10.1016/00401951(90)90180-G
Cassidy, M., Taylor, R.N., Palmer, M.R., Cooper, R.J., Stenlake, C., and Trofimovs, J., 2012. Tracking the magmatic evolution of island arc volcanism: insights from a highprecision $\mathrm{Pb}$ isotope record of Montserrat, Lesser Antilles. Geochemistry, Geophysics, Geosystems, 13(5):1-19. http://dx.doi.org/10.1029/2012GC004064

Cassidy, M., Trofimovs, J., Palmer, M.R., Talling, P.J., Watt, S.F.L., Moreton, S.G., and Taylor, R.N., 2013. Timing and emplacement dynamics of newly recognised mass flow deposits at 8-12 ka offshore Soufrière Hills Volcano, Montserrat: how submarine stratigraphy can complement subaerial eruption histories. Journal of Volcanology and Geothermal Research, 253:1-14. http:// dx.doi.org/10.1016/j.jvolgeores.2012.12.002

Cassidy, M., Trofimovs, J., Watt, S.F.L., Palmer, M.R., Taylor, R.N., Gernon, T.M., Talling, P.J., and Le Friant, A., 2014a. Multi-stage collapse events in the South Soufrière Hills, Montserrat, as recorded in marine sediment cores. In Wadge, G., Robertson, R.E.A., and Voight, B. (Eds.), The Eruption of Soufriere Hills Volcano, Montserrat, from 2000 to 2010. Geological Society Memoirs, 39:383397. http://dx.doi.org/10.1144/M39.20

Cassidy, M., Watt, S.F.L., Palmer, M.R., Trofimovs, J., Symons, W., Maclachlan, S.E., and Stinton, A.J., 2014b. Construction of volcanic records from marine sediment cores: a review and case study (Montserrat, West Indies). Earth-Science Reviews, 138:137-155. http://dx.doi.org/ 10.1016/j.earscirev.2014.08.008

Cassidy, M., Watt, S.F.L., Talling, P.J., Palmer, M.R., Edmonds, M., Jutzeler, M., Wall-Palmer, D., Coussens, M., Gernon, T., Taylor, R.N., Michalik, A., Inglis, E., Breitkreuz, C., Le Friant, A., Ishizuka, O., Boudon, G., McCanta, M.C., Adachi, T., Hornbach, M.J., Colas, S.L., Endo, D., Fujinawa, A., Kataoka, K.S., Maeon, F., Tamura, Y., and Wang, F., 2015. Rapid onset of mafic magmatism facilitated by volcanic edifice collapse. Geophysical Research Letters, 42(12):4778-4785. http:// dx.doi.org/10.1002/2015GL064519

Crutchley, G.J., Karstens, J., Berndt, C., Talling, P.J., Watt, S.F.L, Vardy, M.E., Hühnerbach, V., Urlaub, M., Sarkar, S., Klaeschen, D., Paulatto, M., Le Friant, A., Lebas, E., and Maeno, F., 2013. Insights into the emplacement dynamics of volcanic landslides from high-resolution 3D seismic data acquired offshore Montserrat, Lesser Antilles. Marine Geology, 335:1-15. http://dx.doi.org/ 10.1016/j.margeo.2012.10.004

Davidson, J.P., 1987. Crustal contamination versus subduction zone enrichment: examples from the Lesser Antilles and implications for mantle source compositions of island arc volcanic rocks. Geochimica et Cosmochimica Acta, 51(8):2185-2198. http://dx.doi.org/10.1016/ 0016-7037(87)90268-7

Deplus, C., Le Friant, A., Boudon, G., Komorowski, J.-C., Villement, B., Harford, C., Ségoufin, J., and Chiminée, J.-L., 2001. Submarine evidence for large-scale debris avalanches in the Lesser Antilles arc. Earth and Planetary Science Letters, 192(2):145-157. http://dx.doi.org/ 10.1016/S0012-821X(01)00444-7

Druitt, T.H., and Kokelaar, B.P., 2002. The eruption of Soufrière Hills Volcano, Montserrat, from 1995 to 1999. 
Mem.-Geol. Soc. London, 21:45-69. http://dx.doi.org/ 10.1144/GSL.MEM.2002.021.01.32

Dufrane, S.A., Turner, S., Dosseto, A., and van Soest, M., 2009. Reappraisal of fluid and sediment contributions to Lesser Antilles magmas. Chemical Geology, 265(34):272-278. http://dx.doi.org/10.1016/j.chemgeo.2009.03.030

Expedition 340 Scientists, 2012. Lesser Antilles volcanism and landslides: implications for hazard assessment and long-term magmatic evolution of the arc. Integrated Ocean Drilling Program Preliminary Report, 340. http:// dx.doi.org/10.2204/iodp.pr.340.2012

Expedition 340 Scientists, 2013. Methods. In Le Friant, A., Ishizuka, O., Stroncik, N.A., and the Expedition 340 Scientists, Proceedings of the Integrated Ocean Drilling Program, 340: Tokyo (Integrated Ocean Drilling Program Management International, Inc.). http://dx.doi.org/ 10.2204/iodp.proc.340.102.2013

Feuillard, M., Allegre, C.J., Brandeis, G., Gaulon, R., Le Mouel, J.L., Mercier, J.C., Pozzi, J.P., and Semet, M.P., 1983. The 1975-1977 crisis of la Soufrière Guadeloupe (F.W.I): a still-born magmatic eruption. Journal of Volcanology and Geothermal Research, 16(3-4):317-334. http:/ /dx.doi.org/10.1016/0377-0273(83)90036-7

Folk, R.L., and Ward, W.C., 1957. Brazos River bar [Texas]: a study in the significance of grain size parameters. Journal of Sedimentary Research, 27(1):3-26. http://jsedres.sepmonline.org/cgi/content/abstract/27/1/3

Harford, C.L., Pringle, M.S., Sparks, R.S.J., and Young, S.R., 2002. The volcanic evolution of Montserrat using ${ }^{40} \mathrm{Ar} /$ ${ }^{39} \mathrm{Ar}$ geochronology. Mem.-Geol. Soc. London, 21:93113. http://dx.doi.org/10.1144/

GSL.MEM.2002.021.01.05

Hatfield, R.G., 2015. Data report: stratigraphic correlation of Site U1396 and creation of a composite depth scale and splice. In Le Friant, A., Ishizuka, O., Stroncik, N.A., and the Expedition 340 Scientists, Proc. IODP, 340: Tokyo (Integrated Ocean Drilling Program Management International, Inc.).

Imbrie, J., Hays, J.D., Martinson, D.G., McIntyre, A., Mix, A.C., Morley, J.J., Pisias, N.G., Prell, W.L., and Shackleton, N.J., 1984. The orbital theory of Pleistocene climate: support from a revised chronology of the marine $\delta^{18} \mathrm{O}$ record. In Berger, A., Imbrie, J., Hays, J., Kukla, G., and Saltzman, B. (Eds.), Milankovitch and Climate (Pt. 1): Hingman, MA (D. Riedel Publ. Co.), 269-305.

Ishizuka, O., Taylor, R.N., Milton, J.A., and Nesbitt, R.W., 2003. Fluid-mantle interaction in an intra-oceanic arc: constraints from high-precision $\mathrm{Pb}$ isotopes. Earth Planetary Science Letters, 211(3-4): 221-236. http:// dx.doi.org/10.1016/S0012-821X(03)00201-2

Jutzeler, M., White, J.D.L., Talling, P.J., McCanta, M., Morgan, S., Le Friant, A., and Ishizuka, O., 2014. Coring disturbances in IODP piston cores with implications for offshore record of volcanic events and the Missoula megafloods. Geochemistry, Geophysics, Geosystems, 15(9):3572-3590. http://dx.doi.org/10.1002/ 2014GC005447

Kameo, K., and Bralower, T.J., 2000. Neogene calcareous nannofossil biostratigraphy of Sites 998, 999, and 1000,
Caribbean Sea. In Leckie, R.M., Sigurdsson, H., Acton, G.D., and Draper, G. (Eds.), Proceedings of the Ocean Drilling Program, Scientific Results, 165: College Station, TX (Ocean Drilling Program), 3-17. http://dx.doi.org/ 10.2973/odp.proc.sr.165.012.2000

Karstens, J., Crutchley, G.J., Berndt, C., Talling, P.J., Watt, S.F.L., Hühnerbach, V., Le Friant, A., Lebas, E., and Trofimovs, J., 2013. Emplacement of pyroclastic deposits offshore Montserrat: insights from 3D seismic data. Journal of Volcanology and Geothermal Research, 257:1-11. http:/ /dx.doi.org/10.1016/j.jvolgeores.2013.03.004

Kokelaar, B.P., 2002. Setting, chronology and consequences of the eruption of Soufrière Hills Volcano, Montserrat (1995-1999). In Druitt, T., and Kokelaar, P. (Eds.), The Eruption of Soufrière Hills Volcano, Montserrat, from 1995 to 1999. Mem.-Geol. Soc. London, 21:1-43. http://dx.doi.org/10.1144/GSL.MEM.2002.021.01.02

Lebas, E., Le Friant, A., Boudon, G., Watt, S.F.L., Talling, P.J., Feuillet, N., Deplus, C., Berndt, C., and Vardy, M.E., 2011. Multiple widespread landslides during the longterm evolution of a volcanic island: insights from highresolution seismic data, Montserrat, Lesser Antilles. Geochemistry, Geophysics, Geosystems, 12(5):Q05006. http:// dx.doi.org/10.1029/2010GC003451

Le Friant, A., Deplus, C., Boudon, G., Feuillet, N., Trofimovs, J., Komorowski, J.-C., Sparks, R.S.J., Talling, P., Loughlin, S., Palmer, M., and Ryan, G., 2010. Eruption of Soufrière Hills (1995-2009) from an offshore perspective: insights from repeated swath bathymetry surveys. Geophysical Research Letters, 37(11):L11307. http:// dx.doi.org/10.1029/2010GL043580

Le Friant, A., Deplus, C., Boudon, G., Sparks, R.S.J., Trofimovs, J., and Talling, P., 2009. Submarine deposition of volcanicastic material from the 1995-2005 eruptions of Soufrière Hills Volcano, Montserrat. Journal of the Geological Society (London, U. K.), 166:171-182. http:// dx.doi.org/10.1144/0016-76492008-047

Le Friant, A., Harford, C.L., Deplus, C., Boudon, G., Sparks, R.S.J., Herd, R.A., and Komorowski, J.C., 2004. Geomorphological evolution of Montserrat (West Indies): importance of flank collapse and erosional processes. Journal of the Geological Society (London, U. K.), 161(1):147-160. http://dx.doi.org/10.1144/0016764903-017

Le Friant, A., Ishizuka, O., Boudon, G., Palmer, M.R., Talling, P.J., Villemant, B., Adachi, T., Aljahdali, M., Breitkreuz, C., Brunet, M., Caron, B., Coussens, M., Deplus, C., Endo, D., Feuillet, N., Fraas, A.J., Fujinawa, A., Hart, M.B., Hatfield, R.B., Hornbach, M., Jutzeler, M., Kataoka, K.S., Komorowski, J.-C., Lebas, E., Lafuerza, S., Maeno, F., Manga, M., Martínez-Colon, M., McCanta, M., Morgan, S., Saito, T., Slagle, A., Sparks, S., Stinton, A., Stroncik, N., Subramanyam, K.S.V., Tamura, Y., Trofimovs, J., Voight, B., Wall-Palmer, D., Wang, F., and Watt, S.F.L., 2015. Submarine record of volcanic island construction and collapse in the Lesser Antilles arc: first scientific drilling of submarine volcanic island landslides by IODP Expedition 340. Geochemistry, Geophysics, Geosystems, 16(2):420-442. http://dx.doi.org/10.1002/ 2014GC005652 
Le Friant, A., Lock, E.J., Hart, M.B., Boudon, G., Sparks, R.S.J., Leng, M.J., Smart, C.W., Komorowski, J.C., Deplus, C., and Fisher, J.K., 2008. Late Pleistocene tephrochronology of marine sediments adjacent to Montserrat, Lesser Antilles volcanic arc. Journal of the Geological Society (London, U. K.), 165(1):279-289. http:// dx.doi.org/10.1144/0016-76492007-019

Lisiecki, L.E., and Raymo, M.E., 2005. A Pliocene-Pleistocene stack of 57 globally distributed benthic $\delta^{18} \mathrm{O}$ records. Paleoceanography, 20(1):PA1003. http:// dx.doi.org/10.1029/2004PA001071

Martinson, D.G., Pisias, N.G., Hays, J.D., Imbrie, J., Moore, T.C., Jr., and Shackleton, N.J., 1987. Age dating and the orbital theory of the ice ages: development of a highresolution 0 to 300,000-year chronostratigraphy. Quaternary Research, 27(1):1-29. http://dx.doi.org/10.1016/ 0033-5894(87)90046-9

Masson, D.G., 1996. Catastrophic collapse of the volcanic island of Hierro $15 \mathrm{ka}$ ago and the history of landslides in the Canary Islands. Geology, 24(3):231-234. http:// dx.doi.org/10.1130/ 0091-7613(1996)024<0231:CCOTVI>2.3.CO;2

Ogg, J.G., 2012. Geomagnetic polarity time scale. In Gradstein, F.M., Ogg, J.G., Schmitz, M.D., and Ogg, G.M. (Eds.), The Geologic Time Scale 2012: Amsterdam (Elsevier), 85-113. http://dx.doi.org/10.1016/B978-0-44459425-9.00005-6

Pindell, J.L., and Barrett, S.F., 1990. Geologic evolution of the Caribbean region: a plate-tectonic perspective. In Dengo, G., and Case, J.E. (Eds.), The Geology of North America (Vol. H): The Caribbean Region: Boulder, CO (Geological Society of America), 405-432.

Prell, W.L., Imbrie, J., Martinson, D.G., Morley, J.J., Pisias, N.G., Shackleton, N.J., and Streeter, H.F., 1986. Graphic correlation of oxygen isotope stratigraphy: application to the late Quaternary. Paleoceanography, 1(2):137-162. http://dx.doi.org/10.1029/PA001i002p00137

Richter, C., Acton, G., Endris, C., and Radsted, M., 2007. Handbook for shipboard paleomagnetists. Ocean Drilling Program Technical Note, 34. http://dx.doi.org/10.2973/ odp.tn.34.2007

Roobol, M.J., and Smith, A.L., 1998. Pyroclastic stratigraphy of the Soufrière Hills Volcano, Montserratimplications for the present eruption. Geophysical Research Letters, 25(18):3393-3396. http://dx.doi.org/ 10.1029/98GL00643

Smith, A.L., Roobol, M.J., Schellekens, J.H., and Mattioli, G.S., 2007. Prehistoric stratigraphy of the Soufrière Hills-South Soufrière Hills volcanic complex, Montserrat, West Indies. The Journal of Geology, 115(1):115-127. http://dx.doi.org/10.1086/509271

Thirlwall, M.F., 2000. Inter-laboratory and other errors in $\mathrm{Pb}$ isotope analyses investigated using a ${ }^{207} \mathrm{~Pb}-{ }^{204} \mathrm{~Pb}$ double spike. Chemical Geology, 163(1-4):299-322. http:// dx.doi.org/10.1016/S0009-2541(99)00135-7

Trofimovs, J., Amy, L., Boudon, G., Deplus, C., Doyle, E., Fournier, N., Hart, M.B., Komorowski, J.C., Le Friant, A., Lock, E.J., Pudsey, C., Ryan, G., Sparks, R.S.J., and Talling, P.J., 2006. Submarine pyroclastic deposits formed at the Soufrière Hills Volcano, Montserrat (1995-2003): what happens when pyroclastic flows enter the ocean? Geology, 34(7):549-552. http://dx.doi.org/10.1130/ G22424.1

Trofimovs, J., Fisher, J.K., Macdonald, H.A., Talling, P.J., Sparks, R.S.J., Hart, M.B., Smart, C.W., Boudon, G., Deplus, C., Komorowski, J.-C., Le Friant, A., Moreton, S.G., and Leng, M.J., 2010. Evidence for carbonate platform failure during rapid sea-level rise: ca. 14,000 year old bioclastic flow deposits in the Lesser Antilles. Sedimentology, 57(3):735-759. http://dx.doi.org/10.1111/ j.1365-3091.2009.01117.x

Trofimovs, J., Foster, C., Sparks, R.S.J., Loughlin, S., Le Friant, A., Deplus, C., Porritt, L., Christopher, T., Luckett, R., Talling, P.J., Palmer, M.R., and Le Bas, T., 2012. Submarine pyroclastic deposits formed during the 20th May 2006 dome collapse of the Soufrière Hills Volcano, Montserrat. Bulletin of Volcanology, 74(2):391-405. http://dx.doi.org/10.1007/s00445-011-0533-5

Trofimovs, J., Sparks, R.S.J., and Talling, P.J., 2008. Anatomy of a submarine pyroclastic flow and associated turbidity current: July 2003 dome collapse, Soufrière Hills Volcano, Montserrat, West Indies. Sedimentology, 55(3):617-634. http://dx.doi.org/10.1111/j.13653091.2007.00914. $\mathrm{x}$

Trofimovs, J., Talling, P.J., Fisher, J.K., Sparks, R.S.J., Watt, S.F.L., Hart, M.B., Smart, C.W., Le Friant, A., Cassidy, M., Moreton, S.G., and Leng, M.J., 2013. Timing, origin and emplacement dynamics of mass flows offshore of SE Montserrat in the last $110 \mathrm{ka}$ : implications for landslide and tsunami hazards, eruption history, and volcanic island evolution. Geochemistry, Geophysics, Geosystems, 14(2):385-406. http://dx.doi.org/10.1002/ggge.20052

Wade, B.S., Pearson, P.N., Berggren, W.A., and Pälike, H., 2011. Review and revision of Cenozoic tropical planktonic foraminiferal biostratigraphy and calibration to the geomagnetic polarity and astronomical time scale. Earth-Science Reviews, 104(1-3):111-142. http:// dx.doi.org/10.1016/j.earscirev.2010.09.003

Wadge, G., Voight, B., Sparks, R.S.J., Cole, P.D., Loughlin, S.C., and Robertson, R.E.A., 2014. The Eruption of Soufrière Hills Volcano, Montserrat from 2000 to 2010. Memoirs-Geological Society of London, 39:1-40. http:// dx.doi.org/10.1144/M39.1

Wall-Palmer, D., Coussens, M., Talling, P.J., Jutzeler, M., Cassidy, M., Marchant, I., Palmer, M.R., Watt, S.F.L., Smart, C.W., Fisher, J.K., Hart, M.B., Fraass, A., Trofimovs, J., Le Friant, A., Ishizuka, O., Adachi, T., Aljahdali, M., Boudon, G., Breitkreuz, C., Endo, D., Fujinawa, A., Hatfield, R., Hornbach, M.J., Kataoka, K., Lafuerza, S., Maeno, F., Manga, M., Martinez-Colon, M., McCanta, M., Morgan, S., Saito, T., Slagle, A.L., Stinton, A.J., Subramanyam, K.S.V., Tamura, Y., Villemant, B., and Wang, F., 2014. Late Pleistocene stratigraphy of IODP Site U1396 and compiled chronology offshore of south and south west Montserrat, Lesser Antilles. Geochemistry, Geophysics, Geosystems, 15(7):3000-3020. http://dx.doi.org/10.1002/2014GC005402

Watt, S.F.L., Talling, P.J., Vardy, M.E., Heller, V., Hühnerbach, V., Urlaub, M., Sarkar, S., Masson, D.G., Henstock, T.J., Minshull, T.A., Paulatto, M., Le Friant, A., Lebas, E., 
Berndt, C., Crutchley, G.J., Karstens, J., Stinton, A.J., and Maeno, F., 2012a. Combinations of volcanic-flank and seafloor-sediment failure offshore Montserrat, and their implications for tsunami generation. Earth and Planetary Science Letters, 319-320:228-240. http:// dx.doi.org/10.1016/j.epsl.2011.11.032

Watt, S.F.L., Talling, P.J., Vardy, M.E., Masson, D.G., Henstock, T.J., Hühnerbach, V., Minshull, T.A., Urlaub, M., Lebas, E., Le Friant, A., Berndt, C., Crutchley, G.J., and Karstens, J., 2012b. Widespread and progressive seafloor-sediment failure following volcanic debris ava- lanche emplacement: landslide dynamics and timing offshore Montserrat, Lesser Antilles. Marine Geology, 323-325:69-94. http://dx.doi.org/10.1016/j.margeo.2012.08.002

Initial receipt: 16 April 2015

Acceptance: 29 September 2015

Publication: 8 January 2016

MS 340-204 
Figure F1. Topographic map of Montserrat showing location of three IODP sites (U1394, U1395, and U1396). Also shown are the outlines of major landslide deposits, numbered from 1-5 and 8-9 (Lebas et al., 2011; Watt, et al., 2012a, 2012b; Le Friant et al., 2004; Boudon et al., 2007). Gray dots = locations of shallow ( $<5 \mathrm{~m} \mathrm{long)}$ vibrocores from previous studies (Trofimovs et al., 2013; Cassidy et al., 2012a, 2013).

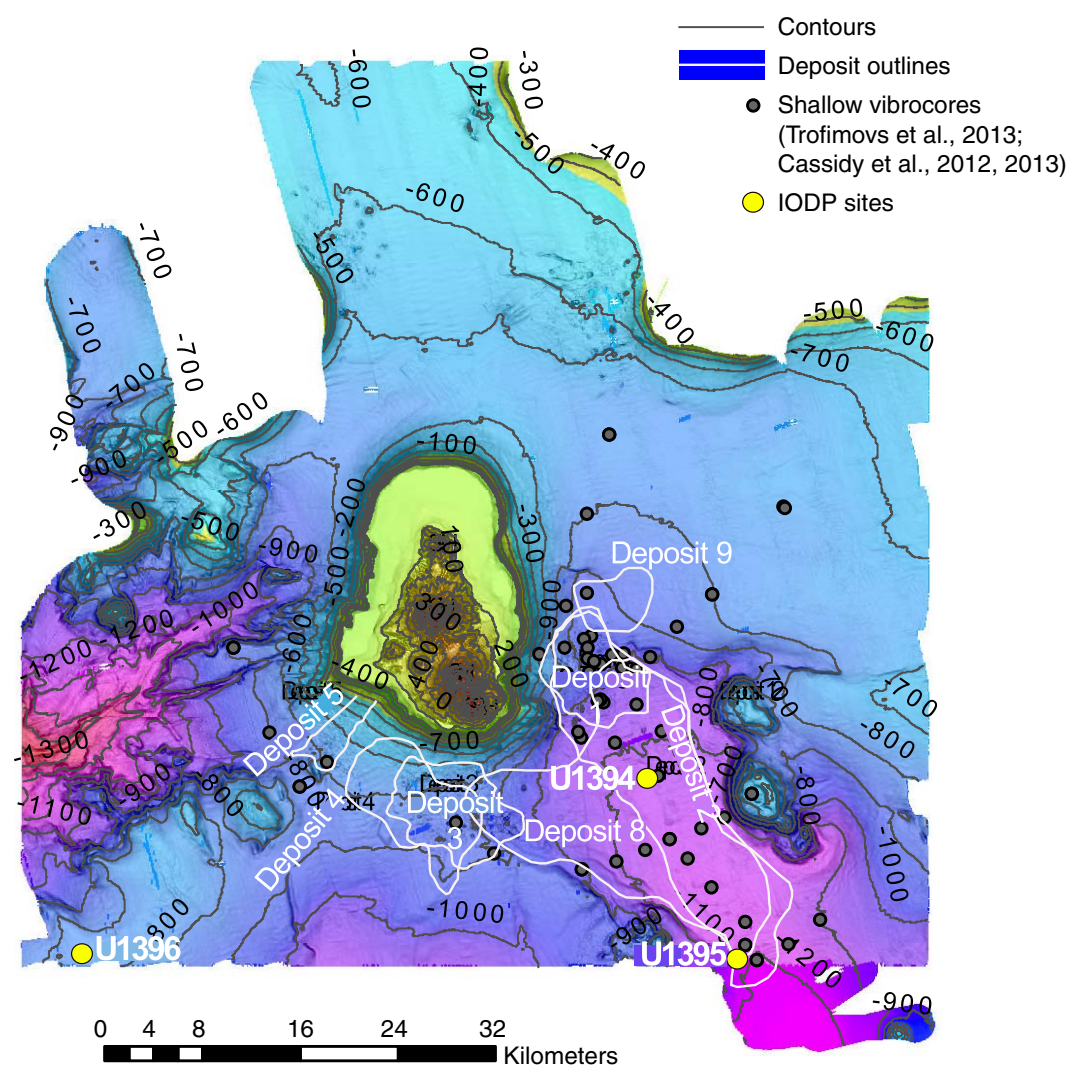


Figure F2. Correlation of units between Expedition 340 Sites U1394 and U1395 to the turbidites described and dated by Trofimovs et al. (2013). Red dots = previous AMS radiocarbon dates from Trofimovs et al. (2103), supplemented by new AMS dates from vibrocores. Black dots $=$ the four radiocarbon dates from Site U1395.

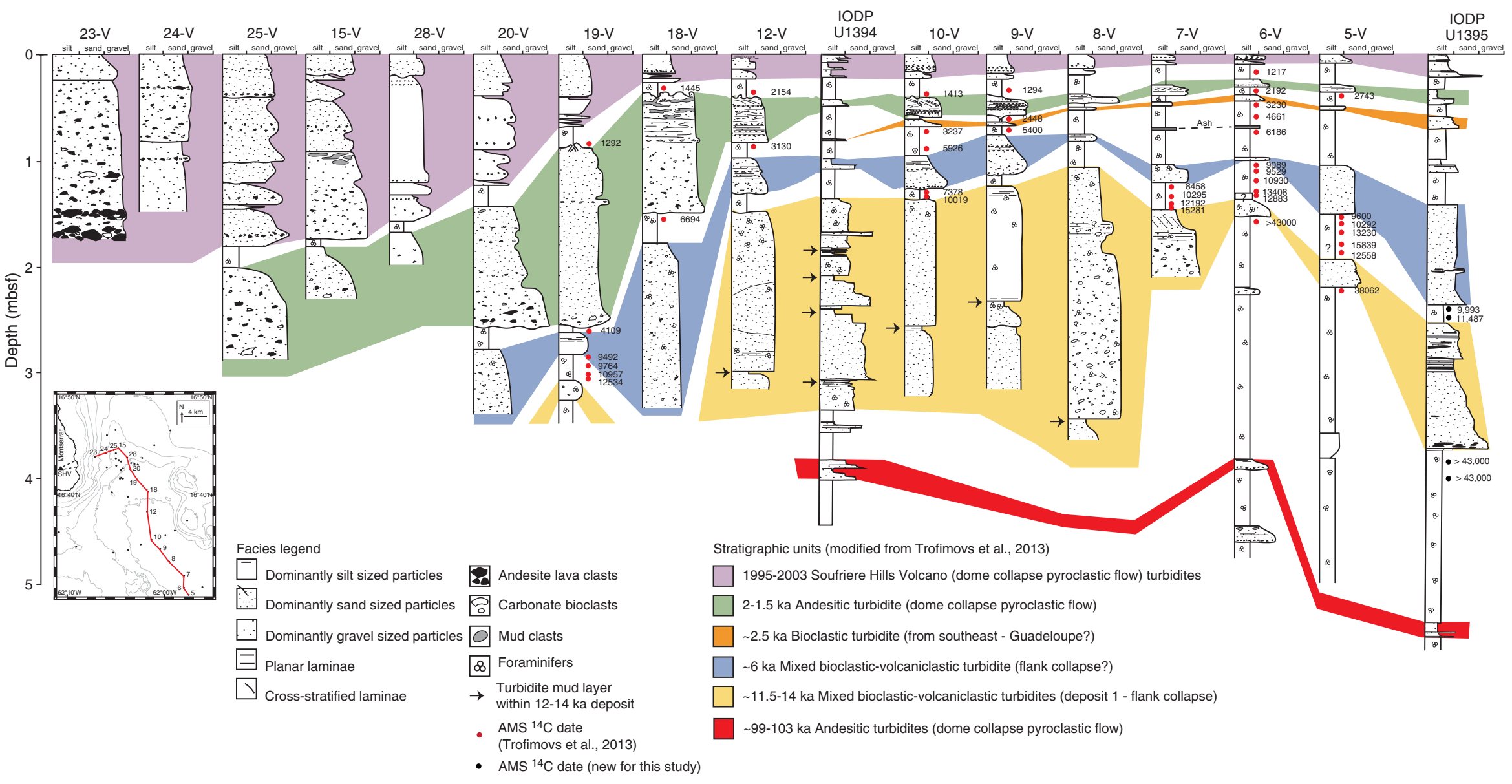


Figure F3. Comparison of oxygen isotope analyses of this study with CAR-MON-2, JR123-6V, JR123-5V (Le Friant et al., 2008; Trofimovs et al., 2013), and the global oxygen isotope curve (Liseicki and Raymo, 2005). Oxygen isotope stages (MIS) are shown. Also shown are unit correlations based on dates and componentry.

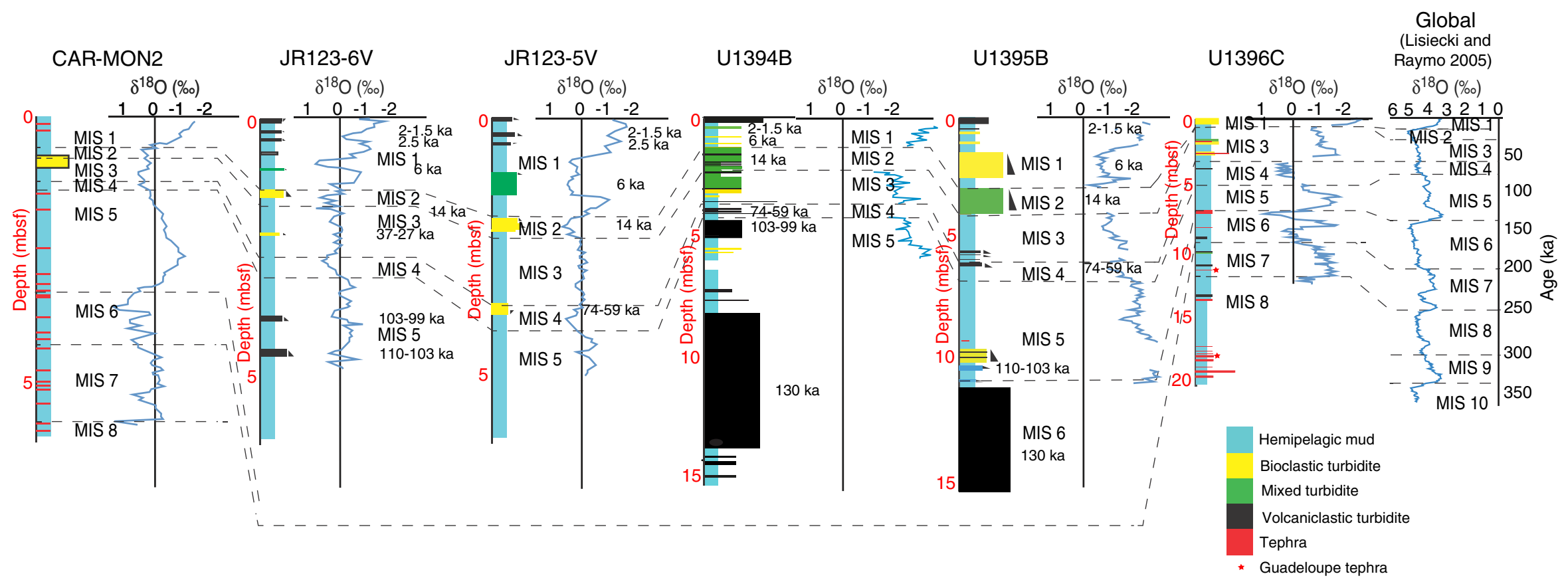


Figure F4. Comparison of $\mathrm{Pb}$ isotope data from Hole U1396C with $\mathrm{Pb}$ data from Montserrat and Guadeloupe obtained from the GEOROC database. (1 = Cassidy et al., 2012; 2 = Davidson, 1987; 3 = Dufrane et al., 2009; 4 $=$ Feuillard et al., 1983; $5=$ Thirlwall, 2000; $6=$ White and Patchett, 1986). The ellipse in the top left indicates the maximum error of $\mathrm{Pb}$ isotope measurements from this study.

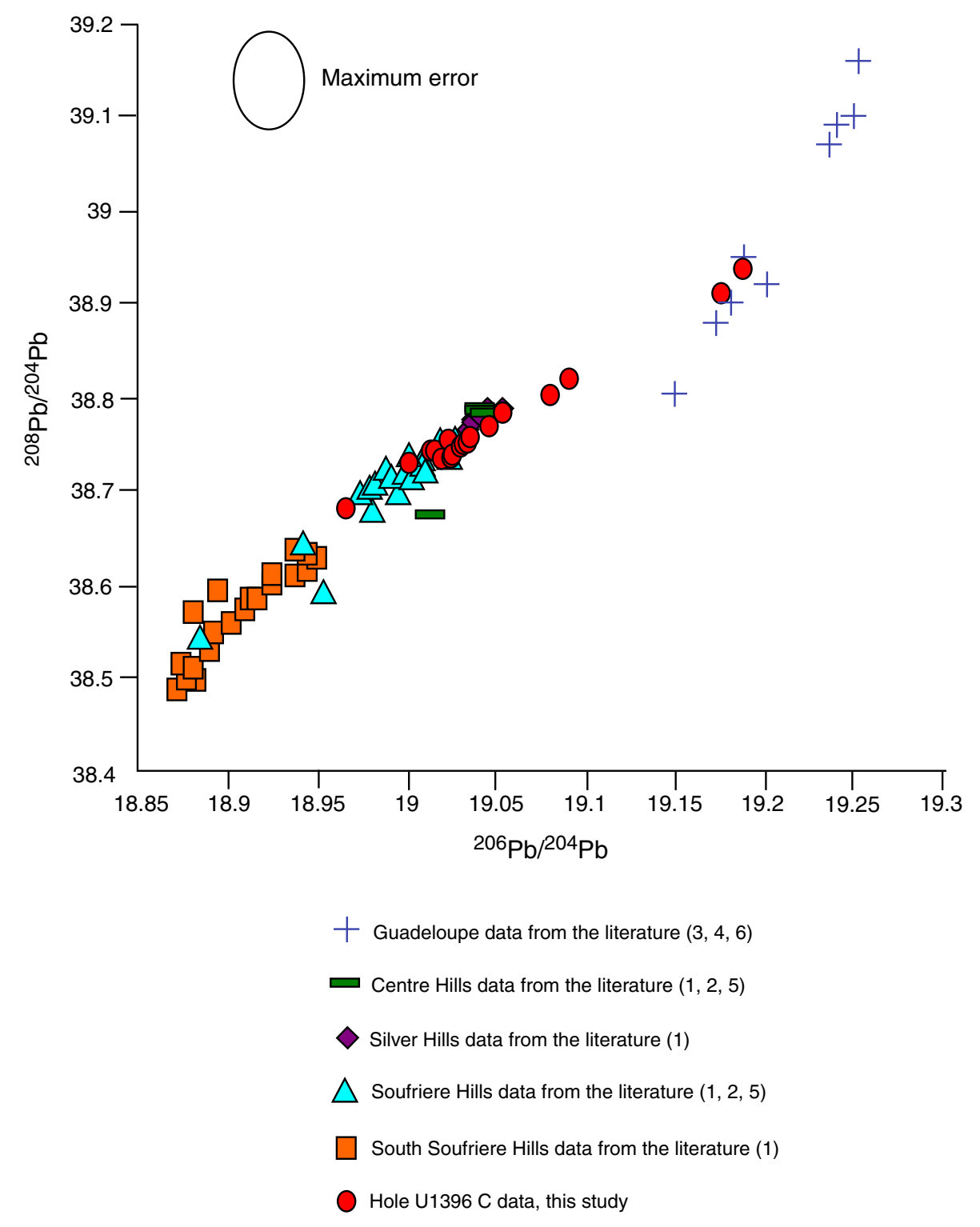


Figure F5. The complete oxygen isotope stratigraphy and percent G. menardii shown for Holes U1394B, U1395B, and U1396C with glacial periods shaded in gray. Also shown is the global oxygen isotope curve (Liseicki and Raymo, 2005). The red line indicates the first occurrence of E. huxleyi. The green box on Hole U1394B identifies a section of stratigraphy that is part of a landslide, thus is not in situ.

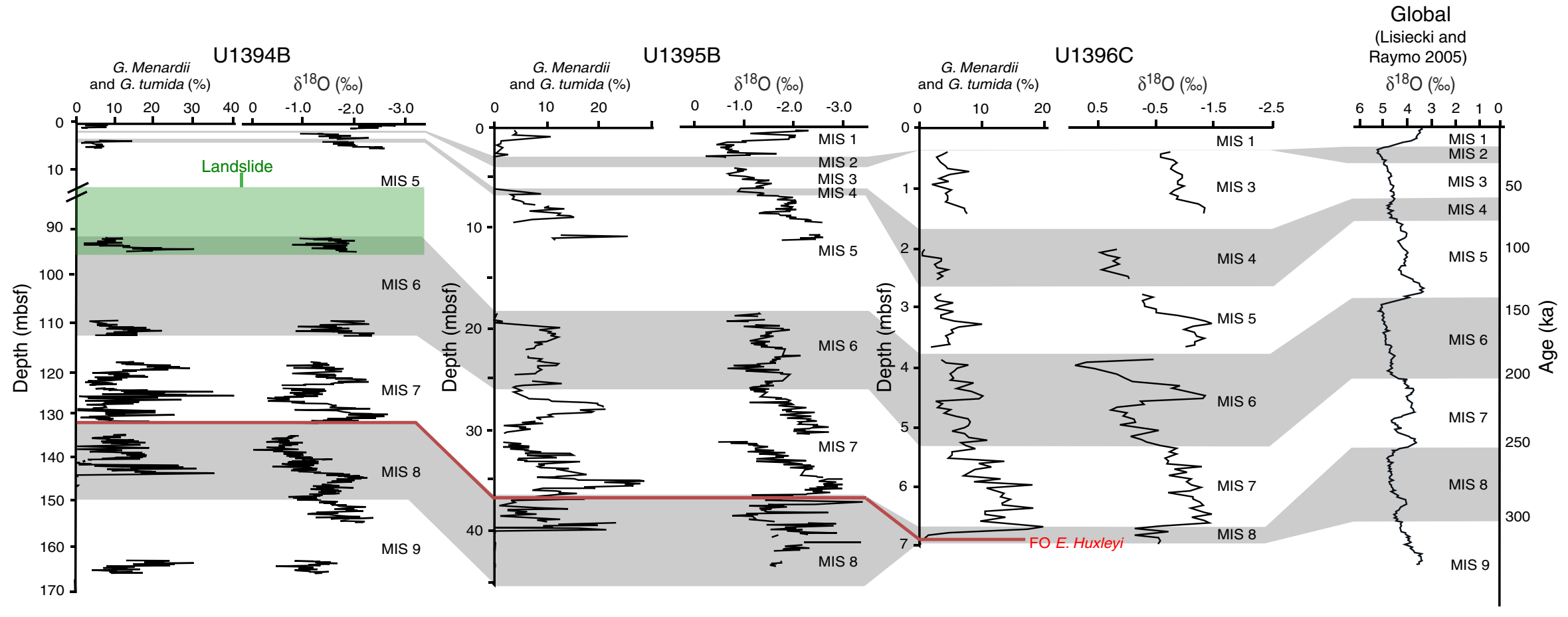


Table T1. Radiocarbon data, Hole U1395B.

\begin{tabular}{cccccc}
\hline Lab sample code & Hole & $\begin{array}{c}\text { Stratigraphic } \\
\text { position }(\mathrm{cm})\end{array}$ & $\begin{array}{c}\text { Conventional } \\
\text { radiocarbon } \\
\text { age (y BP) }\end{array}$ & $\begin{array}{c}\delta^{13} \mathrm{C}_{\text {VPDB }} \\
(\% \circ \pm 0.1)\end{array}$ & $\begin{array}{c}\text { Calibrated age } \\
(\mathrm{y})\end{array}$ \\
\hline SUERC-46961 & U1395B & $258-260$ & 9,993 & 1.1 & $10,475 \pm 58$ \\
SUERC-46962 & U1395B & $265-267$ & 11,489 & 1.1 & $12,617 \pm 41$ \\
SUERC-46965 & U1395B & $409-411$ & 45,806 & 1.2 & $>45,000$ \\
SUERC-46966 & U1395B & $416-418$ & 44,294 & 1 & $>45,000$ \\
\hline
\end{tabular}

$\mathrm{BP}=$ before present.

Table T2. Lead isotope data, Site U1396.

\begin{tabular}{|c|c|c|c|c|c|c|c|c|c|}
\hline Core, section, interval (cm) & ${ }^{206} \mathrm{~Pb} /{ }^{204} \mathrm{~Pb}$ & Error \pm & ${ }^{207} \mathrm{~Pb} /{ }^{204} \mathrm{~Pb}$ & Error \pm & ${ }^{208} \mathrm{~Pb} /{ }^{204} \mathrm{~Pb}$ & Error \pm & \multicolumn{2}{|c|}{$\Delta^{207} \mathrm{~Pb} /{ }^{204} \mathrm{~Pb} \Delta^{208} \mathrm{~Pb} /{ }^{204} \mathrm{~Pb}$} & Source \\
\hline \multicolumn{10}{|l|}{ 340-U1396C- } \\
\hline $2 \mathrm{H}-2,44-45$ & 19.04 & 0.0017 & 15.66 & 0.0016 & 38.76 & 0.005 & 10.72 & 11.07 & Montserrat \\
\hline $2 \mathrm{H}-2,49-50$ & 19.08 & 0.0354 & 15.67 & 0.0325 & 38.81 & 0.1023 & 10.15 & 11.61 & Montserrat \\
\hline $2 \mathrm{H}-2,149-150$ & 19.02 & 0.0053 & 15.65 & 0.0049 & 38.74 & 0.0155 & 10.28 & 11.87 & Montserrat \\
\hline $2 \mathrm{H}-3,3-4$ & 19.03 & 0.0016 & 15.66 & 0.0015 & 38.75 & 0.0047 & 10.97 & 11.6 & Montserrat \\
\hline $2 \mathrm{H}-3$ 10-11 & 19.09 & 0.0015 & 15.67 & 0.0014 & 38.82 & 0.0044 & 10.55 & 12.49 & Montserrat \\
\hline $2 \mathrm{H}-3,55-56$ & 19.19 & 0.009 & 15.69 & 0.0082 & 38.94 & 0.026 & 12.1 & 11.21 & Guadeloupe \\
\hline $2 \mathrm{H}-4,89-90$ & 19.02 & 0.0025 & 15.66 & 0.0023 & 38.74 & 0.0071 & 10.3 & 11.56 & Montserrat \\
\hline $2 \mathrm{H}-4,96-97$ & 19.03 & 0.0022 & 15.66 & 0.002 & 38.75 & 0.0064 & 10.63 & 12.13 & Montserrat \\
\hline $3 \mathrm{H}-1,11-12$ & 19.05 & 0.002 & 15.66 & 0.0019 & 38.78 & 0.0059 & 11.76 & 10.23 & Montserrat \\
\hline $3 \mathrm{H}-1,25-26$ & 19.17 & 0.0016 & 15.69 & 0.0015 & 38.91 & 0.0046 & 10.51 & 11.88 & Guadeloupe \\
\hline $3 \mathrm{H}-1,51-52$ & 19.05 & 0.0017 & 15.66 & 0.0016 & 38.77 & 0.0049 & 9.67 & 11.1 & Montserrat \\
\hline $3 \mathrm{H}-2,25-26$ & 19.03 & 0.0022 & 15.65 & 0.002 & 38.74 & 0.0063 & 10.29 & 12.2 & Montserrat \\
\hline $3 \mathrm{H}-2,59-60$ & 19.03 & 0.0017 & 15.66 & 0.0016 & 38.75 & 0.005 & 10.34 & 12.77 & Montserrat \\
\hline $3 \mathrm{H}-2,65-66$ & 19.02 & 0.0017 & 15.66 & 0.0016 & 38.74 & 0.005 & 10.05 & 12.69 & Montserrat \\
\hline \multicolumn{10}{|l|}{ 340-U1396A- } \\
\hline $1 \mathrm{H}-2,41-42$ & 18.96 & 0.0031 & 15.65 & 0.0029 & 38.68 & 0.0091 & 10.05 & 12.69 & Montserrat \\
\hline $1 \mathrm{H}-2,113-114$ & 19 & 0.0034 & 15.65 & 0.0032 & 38.73 & 0.0099 & 10.17 & 13.27 & Montserrat \\
\hline
\end{tabular}

All samples were taken from the working half of the core. 


\section{Appendix A}

Figure summarizing the stratigraphy of all holes drilled at Sites U1394, U1395, and U1396. Possible correlations between holes are drawn; these are based on age and compositional constraints. This figure is available in oversized format.

\section{Appendix B}

Figure summarizing point componentry data, paleomagnetic data, oxygen isotope data, and biostratigraphic data from Holes U1394A, U1394B, U1395B, and U1396C. Grain size at the $90 \%$ percentile, marine isotope stages, and the global isotope curve from Liseicki and Raymo (2005) are shown (see "Methods" chapter [Expedition 340 scientists, 2013]). This figure is available in oversized format.

\section{Supplementary data tables}

Data shown in "Appendix A" and "Appendix B" are presented in Microsoft Excel format in "Supplementary material." Each table is also available in CSV format.

Table 204_ST01. Grain size data expressed in micrometers. Samples were analyzed by laser in triplicate; results from each analysis and the average result for each sample are shown. See Table 204_ST01.XLSX in "Supplementary material" or 204_ST01.CSV.

Table 204_ST02. Statistics on collected grain size data from GRADISTAT. Samples are from event deposits (turbidites and tephra fall); statistics were cal- culated using average measurements from the laser grain size analyses in Table ST01. Calculations of the mean, sorting, skewness, and kurtosis are given and were calculated using both the method of moments and Folk and Ward (1957). Sizes of the 10\%, 50\%, and $90 \%$ percentile are calculated, and the percentage of each grain size is shown. See Table 204_ST02.XLSX in "Supplementary material" or 204_ST02.CSV.

Table 204_ST03. Point componentry of individual units is given using a field area method. Individual counts and calculated percentages of each component are provided. At least 300 grains were counted. See Table 204_ST03.XLSX in "Supplementary material" or 204_ST03.CSV.

Table 204_ST04. Corrected oxygen and carbon isotope measurements from the analysis of Globigerinoides ruber from hemipelagic mud. Also included is the number of Globorotalia menardii and Globorotalia tumida specimens per 300 foraminifers and the calculated percentage of $G$. menardii and G. tumida. Around the Lesser Antillies G. menardii and G. tumida are difficult to distinguish, as the species appear similar; thus, the foraminifer species have been grouped together. See Table 204_ST04.XLSX in "Supplementary material" or 204_ST04.CSV.

Table 204_ST05. Thicknesses of all units, cumulative thickness of units, and cumulative thickness of overlying hemipelagic mud above all event deposits (tephra falls and turbidites). Unit numbers correspond to numbers in "Appendix B." See Table 204_ST05.XLSX in "Supplementary material" or 204_ST05.CSV. 